\title{
MOON, TIDAL AND DIEL INFLUENCES ON CATCH COMPOSITION OF FISHES IN THE SURF ZONE OF PONTAL DO SUL BEACH, PARANÁ
}

\author{
Rodrigo Santiago Godefroid ${ }^{1,2}$ \\ Marion Hofstaetter ${ }^{1,2}$ \\ Henry L. Spach ${ }^{1}$
}

\begin{abstract}
Fishes were sampled by beach seine during the day and night at the high and low sygygy tides, on a sandy beach at the southeast coast of Brazil. The quantitative results appear to indicate a larger concentration of fish in the surf zone of this beach, in low tides at the start and end of the day. Only eight from the 17 most abundant taxa, appeared to have been influenced singly or in combination by the factors of the moon, day, night and tide.

KEY WORDS. Brazil, diel changes, fishes, sandy beach, tidal changes
\end{abstract}

Few studies of the fish communities on Brazilian beaches have been performed. Those that do exist have shown a community composed of up to 79 species, mainly in the juvenile stage and with a numerical dominance of a few species (PAIVA-Filho et al. 1987; MonTEIRO-NETO et al. 1990; GraÇA LOPES et al. 1993; SAUL \& CUNNINGHAM 1995).

No study has been designed to investigate the changes in abundance of fishes on a Brazilian sandy beach over tidal and diel cycles. The present work analyzes the possible effects of moon, time of the day and tidal stage on abundance of fishes in the surf zone of the beach at Pontal do Sul, Paraná.

\section{MATERIAL AND METHODS}

Samples were obtained in the surf zone of the beach at Pontal do Sul, Paraná State (Fig. 1), with a beach seine (mesh of $1 \mathrm{~mm}, 18 \mathrm{~m}$ in length and $2 \mathrm{~m}$ in height), between May 1993 and April 1994, on a bimonthly bases, during the day and the night at the high and low syzygy tides. The collections were made in the same direction as the current, at a depth which never surpassed $1.70 \mathrm{~m}$ along a $100 \mathrm{mt}$. strip paralel to the beach.

1) Centro de Estudos do Mar, Universidade Federal do Paraná. Avenida Beira Mar, $83255-000$ Pontal do Paraná, Paraná, Brasil.

2) Curso de Pós-graduação em Zoologia, Departamento de Zoologia, Universidade Federal do Paraná. Caixa Postal 19020, 81531-990 Curitiba, Paraná, Brasil. 
In order to evaluate the influence of the moon, tide and time of day on the mean values of the captures in numbers of species, number of individuals and weight, as well as the mean capture estimated from the density data $\log (x+1)$ transformed from the 17 most abundant taxa, the three-way variance analysis (Model I), with three fixed factors was used. Posteriorly, the least significant difference test (LSD), a post hoc comparisons of means was performed (SOKAL \& ROHLF 1981).

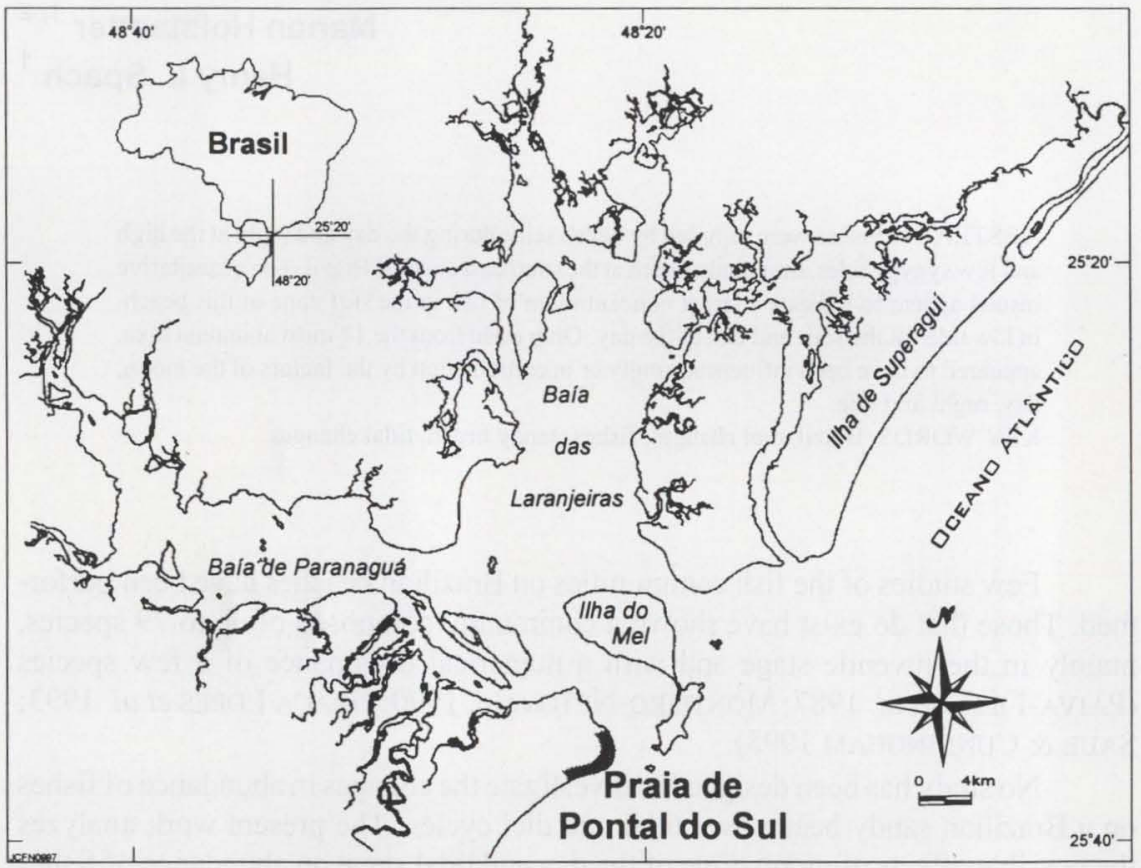

Fig. 1. Paranagua's estuary, showing the location of the sample site.

\section{RESULTS}

A total of 14,516 fish, for the majority in the juvenile and larval stages, were captured, comprising 32 families, 51 genera and 70 species. The analysis revealed that the capture in number of species, appeared to have been influenced only by the tide, with means per throw significantly greater in the low tide in comparison with the high tide. In relation to the number of individuals, significant differences between the mean values per throw could be observed in comparison between the tides and between daytime and nighttime, the larger means being at low tide and during the day. Also, with respect to the mean weight of the capture, the differences between the means were significant only in comparison between the daytime and nighttime samples, with the higher weights occurring during the daytime (Tab. I). 
Table I. Results of variance analysis evaluating the effect of different sampling conditions on the mean number of species, fish and total mean weight of the captures obtained with beach seine at Pontal do Sul, between May, 1993 and April, 1994. (NM) New moon, (FM) full moon, (D) daytime, (N) nightime, (L) low tide, $(\mathrm{H})$ high tide, $\left(^{*}\right)$ significant $p<0,05$, (NS) non-significant.

\begin{tabular}{|c|c|c|c|c|c|c|c|c|c|c|c|c|c|}
\hline \multirow{3}{*}{ Sampling conditions } & \multicolumn{13}{|c|}{ Variance analysis } \\
\hline & \multirow{2}{*}{$\begin{array}{l}\mathrm{NM} \times \mathrm{FM} \\
\mathrm{F}\end{array}$} & \multicolumn{2}{|c|}{$\mathrm{D} \times \mathrm{N}$} & \multicolumn{2}{|c|}{$\mathrm{L} \times \mathrm{H}$} & \multicolumn{2}{|c|}{$\begin{array}{c}\mathrm{NMD} \times \mathrm{NMN} \\
\times \\
\mathrm{FMD} \\
\times \mathrm{FMN}\end{array}$} & \multicolumn{2}{|c|}{$\begin{array}{c}\text { NML } \times \text { NMH } \\
\times \\
\text { FML } \times \text { FMH }\end{array}$} & \multicolumn{2}{|c|}{$\begin{array}{c}L D \times P D \\
\times \\
L N \times H N\end{array}$} & \multicolumn{2}{|c|}{$\begin{array}{l}\text { NMDL } \times \text { NMDH } \times \\
\text { NMNL } \times \text { MNNH } \times \\
\text { FMDL } \times \text { FMDH } \times \\
\text { FMNL } \times \text { FMNH }\end{array}$} \\
\hline & & $\mathrm{F}$ & & $\mathrm{F}$ & & $\mathrm{F}$ & & $\mathrm{F}$ & & $\mathrm{F}$ & & $\mathrm{F}$ & \\
\hline Number of species & 1.09 NS & 2.47 & NS & 8.73 & * & 0.6600 & NS & 1.60 & NS & 0.12 & NS & 0,0005 & NS \\
\hline Number of fish & 0.37 NS & 4.51 & * & 5.37 & * & 0.0005 & NS & 1.94 & NS & 0.22 & NS & 0.5700 & NS \\
\hline Weight (g) & $2.10 \mathrm{NS}$ & 8.45 & $*$ & 0.55 & NS & 0.0300 & NS & 2.68 & NS & 0.40 & NS & 0.5400 & NS \\
\hline
\end{tabular}

The abundance means of each of the selected species, with the exception of Anchoa lyolepsis (Evermann \& Marsh, 1902), Anchoa parva (Fowler, 1976), Xenomelaniris brasiliensis (Quoy \& Gaimard, 1824), Trachinotus carolinus (Linnaeus, 1766), Eucinostomus spp., Menticirrhus americanus (Linnaeus, 1758), Micropogonias furnieri (Desmarest, 1823), Umbrina coroides (Cuvier, 1830) and Mugil gaimardianus (Desmarest, 1831), appeared to have been influenced singly or in combination by the factors of the moon, day, night and tide (Tab. II). Harengula clupeola (Cuvier, 1829) was collected in a significantly higher mean abundance in the daylight period in comparison with the nighttime. At low tide the mean abundance of the species Sardinella brasiliensis (Steindachner, 1789) was significantly greater than that in the high tide. In the species Anchoa tricolor (Agassiz, 1829) considerable differences between the means were present between the daytime and the nighttime samples and between the tides, being on the average, greater during the daytime and at low tide. Concerning the species Hyporhamphus unifasciatus (Ranzani, 1842), statistical differences were present in the combination of the daytime and nighttime factors with the tide, with greater mean values not significantly different from each other in the nighttime high tide and the daytime and nighttime low tide, the latter not differing significantly from the mean value of the daytime high tide. In Oligoplites saurus (Bloch \& Schneider, 1801), only in the combined conditions between the factors of the moon and time of day, were the differences between the means significant, with greater and similar mean values in the daytime new moon and daytime and nighttime full moon, the last two not differentiating significantly from the means that were obtained in the nighttime period of the new moon. In the species Eucinostomus argenteus (Baird \& Girard, 1854) higher mean captures were obtained at the low tide in comparison with the high tide, the same having been observed for the species Eucinostomus gula (Cuvier, 1830). In Menticirrhus spp. the mean abundance was significantly greater in the nighttime (Tab. II).

\section{DISCUSSION}

Correlations between the diversity and biomass in number and weight, with the tide and time of day, were observed in various studies performed on the ichthyofauna associated with the beaches. The greater diversity in the low tide 
catches, independent of the time of day, observed at Pontal do Sul, was also present in the collections of DELANCEY (1989) on the American East coast. While the ichthyofauna of Pontal do Sul, apparently, maintains between daytime and nighttime species composition, in other beaches this species composition appears to change between these periods (LASIAK 1984; GIBSON et al. 1993).

Table II. Results of variance analysis evaluating the effect of different sampling conditions on the mean abundance of main species captured with beach seine net at the beach of Pontal do Sul, between May, 1993 and April, 1994. (NM) New moon, (FM) Full moon, (D) daytime, (N) nightime, (L) low tide, (H) high tide, (LSD) least significant difference, $\left(^{*}\right)$ significant $p<0,05$, (NS) non-significant.

\begin{tabular}{|c|c|c|c|c|c|c|c|}
\hline \multirow{3}{*}{ Species } & \multicolumn{7}{|c|}{ Variance analysis } \\
\hline & $\mathrm{NM} \times \mathrm{FM}$ & $\mathrm{D} \times \mathrm{N}$ & $\mathrm{L} \times \mathrm{H}$ & $\begin{array}{c}\text { NMD } \times \text { NMN } \\
\times \\
\text { FMD } \times \text { FMN }\end{array}$ & $\begin{array}{c}\text { NML } \times \text { NMH } \\
\times \\
\text { FML } \times \text { FMH }\end{array}$ & $\begin{array}{c}\mathrm{LD} \times \mathrm{PD} \\
\times \\
\mathrm{LN} \times \mathrm{HN}\end{array}$ & $\begin{array}{l}\text { NMDL } \times \text { NMDH } \times \\
\text { NMNL } \times \text { MNNH } \times \\
\text { FMDL } \times \text { FMDH } \times \\
\text { FMNL } \times \text { FMNH }\end{array}$ \\
\hline & $\mathrm{F}$ & $\mathrm{F}$ & $\mathrm{F}$ & $\mathrm{F}$ & $\mathrm{F}$ & $\mathrm{F}$ & $\mathrm{F}$ \\
\hline Anchoa lyolepis & $0.2100 \mathrm{NS}$ & $1.69 \mathrm{NS}$ & 3.07 NS & $1.240 \mathrm{NS}$ & 0.06 NS & $0.48 \mathrm{NS}$ & 0.83 NS \\
\hline Anchoa parva & $0.0900 \mathrm{NS}$ & $0.16 \mathrm{NS}$ & $2.50 \mathrm{NS}$ & $0.070 \mathrm{NS}$ & $0.01 \mathrm{NS}$ & $2.33 \mathrm{NS}$ & 0.02 NS \\
\hline Anchoa tricolor & $0.8600 \mathrm{NS}$ & $6.76^{*}$ & $19.09^{*}$ & $1.670 \mathrm{NS}$ & $0.01 \mathrm{NS}$ & $1.50 \mathrm{NS}$ & $0.47 \mathrm{NS}$ \\
\hline Harengula clupeola & $0.9100 \mathrm{NS}$ & $17.65^{*}$ & $2.50 \mathrm{NS}$ & $0.004 \mathrm{NS}$ & 1.93 NS & $1.65 \mathrm{NS}$ & 3.49 NS \\
\hline Sardinella brasiliensis & $0.7700 \mathrm{NS}$ & $0.58 \mathrm{NS}$ & $7.36^{*}$ & $0.070 \mathrm{NS}$ & 0.94 NS & 0.03 NS & $0.12 \mathrm{NS}$ \\
\hline Xenomelaniris brasiliensis & $0.4600 \mathrm{NS}$ & $3.38 \mathrm{NS}$ & $0.71 \mathrm{NS}$ & $1.510 \mathrm{NS}$ & $0.34 \mathrm{NS}$ & 1.95 NS & $1.50 \mathrm{NS}$ \\
\hline Hyporhamphus unifasciatus & $0.1000 \mathrm{NS}$ & 0.38 NS & 3.85 NS & $0.050 \mathrm{NS}$ & 0.08 NS & $6.79 * 2$ & $0.15 \mathrm{NS}$ \\
\hline Oligoplites saurus & $0.0008 \mathrm{NS}$ & $1.00 \mathrm{NS}$ & 1.65 NS & $4.970 * 1$ & $0.41 \mathrm{NS}$ & $0.37 \mathrm{NS}$ & 2.51 NS \\
\hline Trachinotus carolinus & 0.0200 NS & $1.31 \mathrm{NS}$ & 1.76 NS & $0.210 \mathrm{NS}$ & $2.00 \mathrm{NS}$ & 0.72 NS & $0.70 \mathrm{NS}$ \\
\hline Eucinostomus argenteus & $2.2400 \mathrm{NS}$ & $0.24 \mathrm{NS}$ & $7.09^{*}$ & $0.010 \mathrm{NS}$ & 0.67 NS & $0.97 \mathrm{NS}$ & 0.13 NS \\
\hline Eucinostomus gula & $2.7700 \mathrm{NS}$ & $0.58 \mathrm{NS}$ & $6.27^{*}$ & 0.080 NS & 2.77 NS & $0.58 \mathrm{NS}$ & $0.08 \mathrm{NS}$ \\
\hline Eucinostomus spp. & $1.7100 \mathrm{NS}$ & 1.42 NS & 3.11 NS & $0.090 \mathrm{NS}$ & $0.06 \mathrm{NS}$ & 1.05 NS & $0.23 \mathrm{NS}$ \\
\hline Menticirrhus americanus & $2.9100 \mathrm{NS}$ & 3.32 NS & 1.73 NS & $2.190 \mathrm{NS}$ & 0.03 NS & $0.09 \mathrm{NS}$ & $0.17 \mathrm{NS}$ \\
\hline Menticirrhus spp. & $0.1600 \mathrm{NS}$ & $4.17^{*}$ & $0.61 \mathrm{NS}$ & $0.370 \mathrm{NS}$ & $1.06 \mathrm{NS}$ & $0.32 \mathrm{NS}$ & 1.54 NS \\
\hline Micropogonias furnieri & $0.1300 \mathrm{NS}$ & $0.41 \mathrm{NS}$ & 3.47 NS & $0.330 \mathrm{NS}$ & $0.56 \mathrm{NS}$ & $0.06 \mathrm{NS}$ & $0.03 \mathrm{NS}$ \\
\hline Umbrina coroides & 0.0200 NS & $3.70 \mathrm{NS}$ & $3.70 \mathrm{NS}$ & $0.130 \mathrm{NS}$ & 0.07 NS & 1.96 NS & 0.06 NS \\
\hline Mugil gaimardianus & $0.1800 \mathrm{NS}$ & $0.04 \mathrm{NS}$ & 0.97 NS & $0.190 \mathrm{NS}$ & $0.48 \mathrm{NS}$ & 1.04 NS & $0.04 \mathrm{NS}$ \\
\hline
\end{tabular}

$\left({ }^{*}\right)$ LSD: NMD FMD FMN NMN; $\left(*^{2}\right)$ LSD: LD HN LN HD

A greater efficiency in the early morning low tide capture occurred, not only in this work, but also in the samplings performed by LASIAK (1984). In other areas, despite the absence of correlation with the tide, again a greater number of individuals were present in the early morning catches (MODDE \& Ross 1981; Ross et al. 1987). On the other hand, large captures at the low tide, nighttime, was characteristic of a Scottish beach (GIBSON et al. 1993).

The variations of weight biomass with the tide cycle, were not significant in the surf zone of the the beach at Pontal do Sul, however, on the average, the weight biomass was greater during the daytime collections. This result differed from those obtained by LASIAK (1984) and GIBSON et al. (1993), who observed higher weight biomass during the low tide nighttime. These results appear to indicate, for the studied area, a greater concentration of fish in the surf zone at the beginning of the morning and night. 


\section{REFERENCES}

DELANCEY, L.B. 1989. Trophic relationship in the surf zone during the summer at Folly Beach, South Cardina. Jour. Coast. Res. 5 (3): 477-488.

GIBSON, R.N.; A.D. ANSELL \& L. RoBB. 1993. Seasonal and annual variations in abundance and species composition of fish and macrocrustacean communities on a Scottish sandy beach. Mar. Ecol. Prog. Ser. 98: 89-105.

GraÇA Lopes, R.; E. Severino Rodrigues; A. Puzzi; J.B. Pita; J.A.P. Coelho \& M.L. FrEITAS. 1993. Levantamento ictiofaunístico em um ponto fixo na Baía de Santos, Estado de São Paulo, Brasil. Bol. Inst. Pesca, São Paulo, 20: 7-20.

LASIAK, T.A. 1984. Structural aspects of the surf zone fish assemblage at King's Beach, Algoa Bay, South Africa: Short - term fluctuations. Est. Coast. Shelf Sci. 18: $347-360$.

MODDE, T. \& S.T. Ross. 1981. Seasonality of fishes occuping a surf zone habitat in the northern Gulf of Mexico. Fish. Bull. U.S. 78 (4): 911-922.

Monteiro-Neto, C.; C. Blacher; A.A.S. Laurent; F.N. SnizeK; M.B. CANOZZI \& L.L.C. DE A. TABAJARA. 1990. Estrutura da comunidade de peixes em águas rasas na região de Laguna, Santa Catarina, Brasil. Atlântica, Rio Grande, 12 (2): 53-69.

Paiva Filho, A.M.; R. Giannini; F.B. Ribeiro Neto \& J.M.M. Schmiegelow. 1987. Ictiofauna do complexo Baía Estuário de Santos e São Vicente, SP, Brasil. Relat. Int. Inst. Ocenogr. Univ. São Paulo. 17: 1-10.

Ross, S.T.; R.H. MCMICHAEL \& D.L. RUPLE. 1987. Seasonal and diel variation in the standing crop of fishes and macroinvertebrates from a Gulf of Mexico surf zone. East. Coast. Shelf Sci. 25: 391-412.

SAUL, A.C. \& P.T.M. CunNINGHAM. 1995. Comunidade ictiofaunística da Ilha do Bom Abrigo, Cananéia, São Paulo, Brasil. 2 - Lanço. Arq. Biol. Tecnol., Curitiba, 38 (4): 1053-1069.

SoKal, R.R. \& F.J. RoHLF. 1981. Biometry. New York, W.H. Freeman and Company, 859p.

Recebido em 02.V.1997; aceito em 03.VIII.1998. 